\title{
The Problem of Law and Order in Muslim Civilisation: A Hobbesian Perspective
}

\author{
Jan-Erik Lane ${ }^{1}$ \\ ${ }^{1}$ An Independent Scholar \\ Correspondence: Jan-Erik Lane. E-mail: janeklane@gmail.com
}

Received: August 4, 2014 Accepted: September 10, 2014 Online Published: November 5, 2014

doi:10.5539/jpl.v7n4p32 URL: http://dx.doi.org/10.5539/jpl.v7n4p32

\begin{abstract}
As several Muslim countries have fallen into the set of failed states, one would be interested in searching for an explanation of anarchy within the Islamic civilisation. Religious and ethnic cleavages together with rebel fighting has turned countries like Libya, Mail, Nigeria, Somalia, Gaza, Syria, Iraq, Afghanistan and Pakistan into anarchic societies without functioning government. The lack of law and order also plagues Egypt, Bahrain and Bangladesh. Why is there now so much political violence in the Moslem world? The sufferings of ordinary Muslims from government breakdown and sectarian clashes as well as rebel fighting are such that many people have to leave and live elsewhere.
\end{abstract}

Keywords: Hobbes, Hobbesian perspective, political violence, Islamic Law, Sharia, Roman Law, Sunni, Shia, political Islam, rebel groups, Jihadism, terrorism, Boko Haram, Isis, Abu Bakr al-Baghdad, Al-Shabaab, Talibans, religious tolerance, Averroism versus Salafism, constitutional law

\section{Introduction}

The on-going political violence in the Muslim civilization, involving huge numbers of death and casualties as well as destruction of capital and facilities including historical world heritage sites, calls for an analysis. How to understand the immense clashes and growing tensions within the Islam civilization? The coming and spread of anarchy in several Muslim countries has a complex background involving both complex social structure (clans, tribes, ethnies, nations) and the mosaic carpet of religious sects (Sunnis, Shias, Alewis, Alawites, Ismailis. Druzes). In addition, there is the legacy of the political history of Western interference, especially colonialism. The disastrous effects of the US led invasion of Iraq cannot be overestimated. Yet, here I will concentrate upon the relevance of and the implications for the nature of Islamic Law, Sharia, for the state and political violence.

Political stability is the most relevant measuring rod for evaluating politics in Moslem societies and states. In the literature on political Islam and the evolution of the Muslim states after independence as well as the rise of many separate states within the Arab civilisation, the basic evaluation is offered by the theory of democracy. Thus, we underline the immense search for the democratic regime in the Moslem civilisation, including the so-called "Arb Spring". But there is little democracy in the Islamic civilisation. What Muslims need is first and foremost political stability, i.e. law and order.

In this article, I will look for the institutional deficit in Islam when it comes to laws that gurantee political stability. This amounts to a Hobbesian perspective, bypassing the always repeated democracy discourse.

\section{Hobbesian Perspective upon Political Violence in Muslim Societies and States}

I will concentrate upon two conflicts in Muslim civilisation, namely Sunni against Shia and the Muslim Brotherhood against Sunni and Shia. This simplification excludes several other conflicts that all have an ethnic element involved, such as the Kurdish struggles on various fronts, the clashes in North-western China, the conflicts between Jews or Christians and Moslems, etc. The struggle between Sunni and Shia started with the death of the prophet: Why is it seemingly unresolvable, resulting in so much political violence still today? The rise of the Muslim Brotherhood is an event in the 20th century: What is its rationale in the globalised 21rst century?

The Sunni-Shia tension is to be found in the Syrian civil war, the struggle in Iraq and in Bahrain, in the tension between the Gulf monarchies and Iran. The emergence of the Muslim Brotherhood as a major political force has occurred in Algeria, Egypt, Palestine, Syria, Iraq and Afghanistan. The centuries' long conflict between Sunni 
and Shia shows that only tolerance can work in the Muslim civilisation. This leads us to the question: Why not endorse the rationalism and lack of bigotry with Averroes, or Ibn Rhusd? The strong support for Muslim brotherhood is based upon a new and false interpretation or The Koran, which entail that there is somehow one and only one "correct" or "original" interpretation that must be institutionalised in state and society.

Muslim societies, like all human social systems at the macro level, need law and order to prosper and develop this was the fundamental sight of Thomas Hobbes in Leviathan (1651). It remains as relevant today to the failed states in the world as it was once upon a time for England. Hobbes' emphasis upon political stability as well as law and order has been praised in the history of political theory more for the elegance with which he put forth his message - deductive reasoning on a rationalist basis - than for its actual content. Instead, Locke and Rousseau are generally preferred to Hobbes, because they were semi-democrats or populist democrats. My argument here is that Hobbes could not be more relevant today, especially in relation to massive political violence in several Moslem societies.

One should make a clear distinction between political stability and democracy, following Hobbes' argument that anarchy must be avoided through government intervention in society. Thus, we have the following classification of Muslim countries:

Diagram 1. Political Stability versus Democracies: Countries today with large Moslem populations

\begin{tabular}{|c|c|c|}
\hline Democracy & $\begin{array}{l}\text { Political Stability } \\
\text { Turkey, Niger } \\
\text { Albania, Tunisia }\end{array}$ & $\begin{array}{l}\text { Political Instability or anarchy } \\
\text { Bangladesh, Yemen } \\
\text { Lebanon, Pakistan, Burkina Faso } \\
\text { Iraq, Nigeria, Mali, Chad } \\
\text { Somalia, Kenya, Kyrgyzstan, } \\
\text { Indonesia, Afghanistan, Libya, }\end{array}$ \\
\hline Dictatorship & $\begin{array}{l}\text { Saudi Arabia, Qatar, } \\
\text { Oman, Kuwait, UAE, } \\
\text { Jordan, Morocco, } \\
\text { Brunei, Iran }\end{array}$ & $\begin{array}{l}\text { Egypt, Bahrain, Iran, } \\
\text { Algeria, Central African Republic } \\
\text { Malaysia, Syria, Mauritania } \\
\text { Kazakhstan, } \\
\text { Uzbekistan, Tajikistan, } \\
\text { Turkmenistan }\end{array}$ \\
\hline
\end{tabular}

Diagram 1 shows that political instability and the lack of law and order characterizes the Muslim civilisation today. In the quest for political reforms in the Muslim civilisation, the focus has been exclusively upon the introduction of democracy, bypassing the horrors of political instability and neglecting the absence of law and order. Whether or not for instance Arab countries can sustain a democratic regime, it is still extremely vital that they remain politically stable. The Arab Spring failed almost everywhere, simply unleashing political violence, anarchy and anomie. When an authoritarian regime falls in the Moslem World, then it tends to be replaced by warring rebel groups and fighting clans. The crucial importance of "clanism" for Arab societies and other Moslem states has never been adequately theorised.

Where there is anarchy, Hobbes famously predicted: "the life of man is brutish, nasty, poor and short". The sufferings of Muslims in countries with anarchy or anomie have become so huge that one cannot simply target democracy reforms. As in the Arab Spring, democracy efforts may fail and result only in political instability at an enormous price in lives, casualties and possessions. The worst is the warring rebel and "clanique" society.

If Hobbes were to return to our world now, he would surely point out that Diagram 1 contains very few stable democratic regimes in the Muslim civilisation. And he would probably add that it is better for a Moslem to live under kingship in several of these countries than under anarchy and anomie in many of them.

Political stability as law and order may be identified with the notion of rule of law in the World Bank Governance Project. Government would face the task of upholding a set of minimum rights to due process of law, personal integrity and material possessions. Figure 1 displays how this minimum kind of rule of law, not 
comprising the democratic regime, varies around the globe, according to the WB.

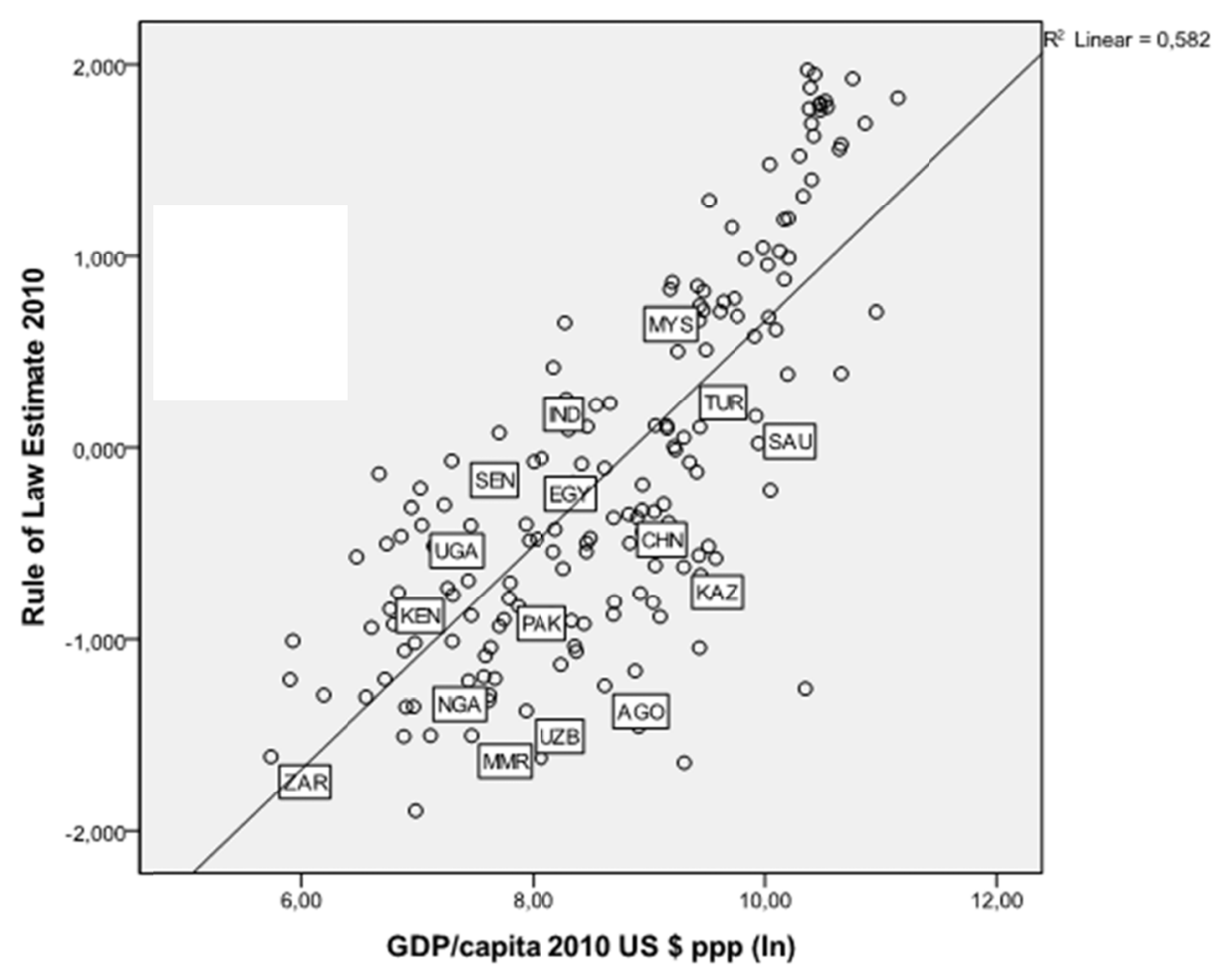

Figure 1. Rule of law: A minimalist interpretation of political stability as law and order

Source: Sources: Kaufmann, D. A. Kraay, and M. Mastruzzi (2012) Worldwide Governance Indicators; World Bank (2012) World Bank Databank.

Political instability in several Moslem countries mean today not only day-to-day turmoil and assassinations, police brutality, lack of legal integrity, arbitrary court decisions, unlawful detentions, torture etc. It also involves something even worse, namely the new feudal order of conflicting rebel groups, heavily armed and most brutal. They fight government but also each other. In so far as the new anarchy and political instability in the Islamic civilisation is religiously motivated, it is, I wish to underline, completely meaningless, only making the life of Moslems miserable.

Let me suggest just two "Gedanken" experiments: First, Gaza is now almost entirely destroyed with thousands of people either killed or wounded seriously, to no avail at all. Gaza might have turned into a tourist haven like the Tel Aviv area with lots of job opportunities and capital investments. Now, it must be rebuilt for the second or third time. The Hamas' strategy is a blatant failure, as the Palestinians could have protested against Israeli land grabs much more effectively by peaceful means than launching thousands of rockets erratically. Second, the civil war in Syria with its enormous sufferings and casualties as well as capital destruction could have been avoided by the employment of the Swiss method of conflict regulation, viz. the referenda. Given that Syrian ethnies and sects were provided with the secure protection of rule of law in the above sense, the power contestation between Syrian type Shias and Sunnis could have handled by international intervention and foreign observers, with no bloodshed what so ever, simple by resorting to a series of referenda. Why, then, is conflict so lethal in the civilisation of Islam, at least so in several of its major countries?

\section{Islam and Present Day Political Violence}

The Islamic civilisation harbours more than 1 million Muslims. They are concentrated in northern Africa, the Middle East, Central and South Asia as well as Indonesia. It has been underlined that the emigration of Muslims to Western countries recently has made Islam "global" (Roy, 2006).

The surge in political violence in the Muslim civilisation is a recent phenomenon, as the number of deaths from domestic violence has increased dramatically the last decade or two. The Algerian civil war took at least 100000 lives and the Syrian civil war bypasses by far that number, which is also probably true of the civil wars in Iraq 
and Afghanistan. The number of casualties is large in several countries like Egypt, Lebanon, Nigeria and Turkey. The material destruction is widespread in Syria, Afghanistan and Sudan and Mali.

Now, the massive political violence in several of the Muslim countries has multiple causes or reasons without doubt. First, there occur ethnic cleavages. Second, there is the long-time struggle over the nature of the regime: dictatorship or democracy. Finally, last but not least there are the clashes between the sects and the religious groups.

It is true that the struggles within Muslim countries comprise much more than the religious clashes between Sunnis and Shias as well as the Jihadists. Besides ethnic cleavages, there is also the search for democracy and human rights. The various conflicts become nested so much that they are not always easily disentangled. However, here I concentrate upon the religious clashes, which really date back to the death of the Prophet, 623 after Christ.

\section{Interpretations of the Koran in Islam}

Comparing religious tensions within the present civilisations of the world, one observes that the situation with Islamic countries is abnormal. Neither the Christian nor the Buddhist civilisations know something similar. It is true that there occurs fundamentalist inspired political violence in the Jewish and Hindu civilisations, but the scale is entirely different.

Yet, one can certainly advance such a simplistic idea that the religion of Mohammed, as propagated in the Koran, is more violent than the other world religions. One only has to bear in mind the enormous fighting within Christianity between Catholics and Protestants or the struggles between sects in Hinduism to recognize that there is nothing especially prone to conflict about the Koran. It is the interpretations of the text and the social practices based upon these interpretations that count.

Over the history of Islam, the Koran has received different interpretations. Actually, the text war put together long after the death of the prophet and there exist competing collections of verses - the basic unit of the Koran. Whether the verses constitute the words of God has been a contentious issue with this religion, resulting in political violence in the $9^{\text {th }}$ century. Although this position is generally regarded as blasphemy today, it is undeniable that the spread between the Salafist on the one hand and the rational interpretations on the other hand is large, to say the least.

This implies strictly the question of scepticism: How to identify the "correct" interpretation of the Koran? It leads to crucial questions about legal and political authority in the Muslim civilisation. One way out of the dilemma of widely different interpretations of a key religious text that attempts to establish the norms of society is to have some form of authority lay down the "correct" interpretation and then proceed to enforce it by all kinds of means.

The close connection between religious dogma and political power became one of the hallmarks of Islam, as it never established an independent church, like Christianity. It was up to the successor of the prophet to maintain religious order and uphold its stated norms in society. Thus, the question of interpretation of the Koran became intimately linked with the successor problem: Who is to be the caliph or the imam? All this got even more confusing, as the Muslim community early divided into two major groups, harbouring entirely different ideas about rulership in Islam.

The problem of interpretation received an early and, as it was thought, final solution with the figh: Islamic jurisprudence would codify what Islam stands for in a set of precepts that could not be denied nor neglected. However, this legalistic approach though highly influential upon later development after 800-900, did not success in arriving at consensus. Thus, there are 4 schools of jurisprudence within Sunni and another school within Shia. Their differences reflect the basic fact about a lack of underlying consensus in the Islamic civilisation, as Sunni schools differ from the Shia school and the Sunni schools differ among themselves as to doctrine and dogmas.

Islam does not contain like Christianity or the religions of India a much elaborated theology. The core of Islam is the set of 5 duties, nothing more. When they are respected, the believer will receive the salvation. This minimalist approach leaves much open to disagreement. And diversity of opinion on religious matters has become typical of Islam. One may ask why this diversity today is conducive to so much political violence within this civilisation, as religious tensions have subsided in the other civilisations of the world?

It is true that there exist sharp differences between the typical Sunni creed and Iranian Shiism. They range over a number of aspects of Islam besides the principal solution to the successor question, such as: 
i) Division of public and private;

ii) Division of mundane and sacred;

iii) Acceptance of modernisation.

It holds generally that average Sunnis tend to be more pragmatic than the average Shia in Iran. Thus, modernisation, secularism, the market economy and democracy is more supported in Sunni majority countries than in Iran, although this may only be a result of the that the theocracy in Tehran does not allow free and fair elections. This stylised picture of the Sunni countries as more moderate than the Shia ones is nothing but a simplification that hides complexity of religious opinions.

The Muslim civilisation holds a carpet of religious diversity where many groups are involved with a bewildering system of beliefs - Just to mention a few:

a) There are at least four kinds of Shiism: twelvers in Iran and Syria, seveners in Lebanon, Syria and India, fivers in Oman as well as the many Shites in Turkey;

b) Muslim brotherhood belongs under Sunni;

c) Sunni harbours both Salafism and Islamic rationality.

This is not the place to sketch the evolution of these tensions between various sects, as it covers the entire history of Islam, both Arab Islam and non-Arab Islam. Instead one must pose the question: Why do differences in religious creed result in acts of political violence. The same question may of course be posed to Christianity and the religions of India.

Religious cleavages are conducive to violence when they concern the distribution of valuable assets in scare supply. The control of these real assets - money, power, taxes, premises, land - is what human beings ultimately fight about, when the conflicts are not solvable through negotiation. Religious creed is a tool for exercising power over human beings, which is why people with different creeds collide when they happen to share the same territory and the same community. It is true that religious emotions may give the conflict between religious groups a special fervour and intransigence, but what is decisive is the access to the control over human beings.

The crucial question in religious conquests or reconquistas is which religious group controls the territory, the political power and the economic resources - Cujus religio, ejus regio, as the Protestants expressed it. The history of Islam is a long succession of power changes, often linked with groups colliding due to differences in creed. The more they collide on the basis of theology, the more vital it becomes to exercise control.

Issue in religious theology can only be resolved by argument, if ever. The most difficult questions that religious groups pose and answer differently concern matters that are metaphysical, such as:

- Is God one or three?

- Could Jesus be the son of both Joseph and God?

- Whom did Mohammed leave power to: his tribe or just his gender Ali?

- Is jihad a religious duty for all Moslems?

- Is Buddha a God or the God?

- Is Krishna really the incarnation of Vishnu?

- Can people receive luck by means of bhakti?

The list above about the mysteries in religion could be made much, much longer. It is all a matter about creed, or religious belief, not reason, or deductive or inductive argument. When people disagree about the answer to such metaphysical questions, they can employ the sword to find a speedy but always temporary solution, like Alexander at Gordon. But conflict cannot settle the matter, only offering a most short lived "solution". However, resort to the sword gives access to the real assets that people collide about: power, prestige, money, land, etc.

Religious purity is no doubt essential to some people with strong religious creed. However, it is one thing for these people to be able and have the right to practice this purity, and quite another matter to attempt to impose it upon other people with different minds.

\section{Religious Tolerance in Muslim Civilisation}

For an external observer, the tension between Sunnis and Shias appears like a relic from the past. Why can these two Muslim beliefs not co-exist? Since the ideas of the caliphate or the imam are long out of date, Muslim countries having some form of modern constitution with presidentialism or constitutional monarchy, a Muslim 
country can honour religious tolerance, especially among its own Koranic community.

During the so-called golden period of Islam during the medieval ages when there was great diversity of opinion, a solution to the question of reconciling faith with reason was formulated that could have befitted Islam much, if it has been widely endorsed, leading to religious tolerance.

The rise and growing strength of Muslim fundamentalism in an age of globalisation, modern economics and the triumph of the natural sciences is enigmatic. It is widely believed that Islam is somehow responsible for this global paradox, but it would be a fatal mistake to equate the religion of Islam, one of the three great monotheistic traditions, with unreason.

All the world religions have had to take a stand on the relationship between reason and faith: How to handle any conflict between the two? And all the great religions of the world today have devised a modus Vivendi between reason and faith, except Islamic fundamentalism. This is all the more astonishing as Islam was the first of the major religions to work out a tenable solution of how to respect faith while fully employing the faculty of reason and observation. Before Christianity came up with various solutions to this fundamental problem - with Thomas ab Aquino, John Locke and Baruch Spinoza - there was the theory offered by Ibn Rushd or Averroes. It makes him the greatest of medieval philosophers.

The Decisive Treatise sums up the entire debate about reason and faith in the Moslem civilisation with the emerging schools of philosophy and jurisprudence since the Koran was codified around 700 after Christ. Drawing upon the various contributions by inter alia Farabi, Avicenna and Ghazali as well as many other more like the Azelites, Averroes formulates his position in a few arguments. Thus, we have the core of so-called Averroism:

1) The Law or the Book of God (The Koran) obliges the believers to study;

2) Any study must make use of logic, which is the best tool of reasoning;

3) Logic is connected with philosophy, studying both theoretical and practical subjects;

4) A Muslim cannot abstain from either logic or philosophy, as the Book of God commands their study;

5) There can be no contradiction between the message of the Book of God and the truth as stated by logic and philosophy, as any statement of faith that is opposed to truth must be interpreted allegorically;

6) The verses in the Book of God can be interpreted literally or allegorically;

7) When it come allegorical interpretations of the verses, one cannot expect much consensus.

8) Thus, the reading of the Book of God is compatible with freedom of interpretation, except when there is unanimity among believers.

9) What hold for theoretical issue is also true for practical matters, like the governing of the Ummah by law and rational jurisprudence.

Muslims, thus, have to live with two meanings of the Book of God, the literal and the allegorical. So is the case with Jews and Christians, as stated much later by Spinoza. The only conclusion of the predicament of faith and reason is religious tolerance, as with Locke' Letter on Tolerance (1699).

The search for true Islam, as with the Salafists, or the Islamisation of state and society, as with the jihadists, is a meaningless effort. It has very negative consequences for the Muslim civilisation, resulting in endless political violence and the deaths of innocent civilians.

The Koran like the "Sainte Bible" contains beautiful tales, which when not in accordance with scientific reason can only be told in their literal meaning as exactly that: stories, as first emphasize by Spinoza in Tractatus Teologico Politicus (1677). Yet, the first philosopher to realise the double truth - faith and reason - was none other than Averroes from Marrakech.

\section{One Islam - Many Islams}

The basic change in Muslim belief in the $20^{\text {th }}$ century is the emergence of the idea that there is somehow ONE Islam that can practiced one hundred per cent in all aspects of life. When combined with the Salafist approach to the Koran, the chief approach of Muslim Brotherhood appears, namely that idea that only Islam as practised in the $7^{\text {th }}$ century by the prophet and his close followers is the "correct" Islam.

The Salafism of Ibn Taymiyya glorified the past of Islam, but the golden period of the Islamic civilisation did not take place in early Arabia with its tribal practices and life style. Instead, Islam flourished around the lifetime of Taymiyya and up to the Renaissance in all areas of social life: medicine, astronomy, mathematics, philosophy, 
trade, art, etc. Thus, one arrives at the always posed question: Why did the Islamic civilisation decline while the European advanced?

The fundamentalist answer to this central question about the evolution of Islamic civilisation is to look backward, which is of course impossible in the period of globalisation when civilisations are more one than ever and interacting daily in various forms.

The Muslim Brotherhood adds control and force to the Salafist ideals. The people of Islam - Umma - is to be kept in a state and society, completely dominated by the ideal of ancient Islam, as if there really existed ONE Islam. The concept of jihad receives with the MB a new interpretation as legitimate violence for creating a true Muslim society. "Political Islam" turns Salafism into a totalitarian political philosophy with terrorism implications. It has been said about the founder of the MB, al-Banna that he wanted to restore the caliphate that had fallen in 1924 in Istanbul. However, the MB soon developed a much more radical and comprehensive call for change of state procedures and social practices: Islamisation writ large.

The main theoreticians of modern Islamic fundamentalism - Mawdudi, Qutb and Faraj - did not envisage to create a tribal surrounding for the Umma. Instead, they outlined a utopia for a future Islamic state controlling a society structured in accordance with the harshest form of Islamic Law, viz. The Hanbalite interpretation of Sharia, as it exists in Saudi Arabia for instance, although the MB does not accept the figure of Wahab and his interpretation of Islam, as no one can come between the prophet and his community.

The Islamic doctrine of the MB is based on one possible interpretation of the Koran as well as one selection of customs from the Hadith of the Sunna. In the history of Islam, there have been many interpretations of the Koran. Why would the interpretation of the MB be the "correct" one? There exists no criterion for selecting the "correct" practices in the Hadith.

Yet, what is distinctive of the political philosophy of the MB is not the belief in one and only one interpretation of the Koran, but the idea of islamisation of state and society. In involves:

a) One unique set of customs is valid in society, only one;

b) The state must be an Islamic republic, oriented towards the enforcement of the Sharia;

c) Religious leadership of government in the form of charismatic personalities;

d) The use of violent means - jihad - to protect the Islamic republic and to further Islamic objectives abroad.

The endorsement of physical violence has led to the renewed forms of terrorism in the Islamic civilisation, practised by rebels, called jihadists. As a result, some of the Moslem countries are drowned in rebel attacks on the state as well as on civilians.

\section{Logic of Conflict Behaviour}

The question that will be discussed below is why there is so much political violence WITHIN the Muslim civilisation among the Moslems themselves. Thus, I will not take up the conflict between Islam and Judaism or Islam and Hinduism-Buddhism. The conflicts among Muslims are essentially of two types religiously, bypassing ethnic tensions:

1) Sunnis versus Shias

2) Jihadists versus moderate Sunnis and Shias.

The first conflict dates back to the origins of Islam, viz the complete lack of any political philosophy in The Koran. There is not a single word about the political future of the Islamic community - the Umma, when the prophet dies.

As a matter of fact, The Koran launches no political philosophy at all, which could have outlined the rules of political rulership in the Muslim civilisation. The Koran is one hundred per cent religion, with little philosophy and no politics in the sense of institutionalism. The Koran is a continuation of Jewish religion with the claim of being its ultimate culmination of the tradition from The Bible with its monotheism and long series of prophets: Abraham, Moses, Jesus etc. It shares the Jewish opinion that Jesus could not have been the son of God, and it never mentions the real creator of Christianity, namely Paul. The Koran is the re-instatement of the Old Testament writ large plus the claim that Mohammed is the last of the prophets stating the final revelation of God to the humans. Without the Old Testament, no The Koran, as the inspiration is completely comprehensive. But it says nothing about the world to come when the Prophet is no longer alive.

The Koran only outlines a set of rules of the private behaviour of his community, especially regarding marriage, 
heritage and sex, with somewhat special rules for the Prophet. When these rules were worked out in the Islamic jurisprudence (Figh) by adding rules from the sayings and doings of the Prophet (Hadith), In no schools of Islamic jurisprudence does one find public institutionalism, as they all whether Sunni or Shia concentrate upon private behaviour. The Koran is constitution free.

Mohammed ruled on the basis of charismatic authority, breaking tribal leadership prevalent on the Arabian peninsula. This unique combination of political and religious power goes under the name of the caliphate. It has two profound problems:

1) How is the caliph to be chosen?

2) What are the basic rules of the exercise of his power?

There exists still no solution to these two basic problems of any rulership, one thousand and almost four hundred year after the Prophet. The outcome is political instability all over the Muslim civilisation.

When the leader of the so-called Islamic State in Syria and Iraq proclaims himself caliph, then this is just one method employed - auto-proclamation. But it is all an historical atavism, as the last real caliph died when Bagdad was destroyed by the Mongols 1257 . Since that the caliph was merely an honorary title, finally abolished by Ataturk 1924.

The institutional deficit in The Koran opened up for decades and centuries of power struggles between different power pretenders, Arabs, Persians, Berbers, Mongols, Turks, Kurds, Indians, etc. In a few Moslem countries, systems of traditional authority were established with some stability, i.e. kingdoms, sultanates and emirates. But there never occurred a full institutionalisation of the rules inherent in rule of law for any longer time period. Thus, Muslim rulership has often been based upon naked power, which is conducive to the massive occurrence of political violence.

The institutional deficit of The Koran had an immediate result after the death of the Prophet, given the two omissions mentioned above (i-ii). As Ali, the nephew of the Prophet claimed to be named caliph, the civil war between Sunnis and Shia began, which has not ended to this day.

\section{The Sunni-Shia Clash Is without Sense}

The Sunni-Shia conflict operates at both micro and micro level. Locally, the occurs communal violence against innocents on a regular basis, including car bombs and suicide bombers, At the state level, the clash between Iran and its Arab neighbours has a long legacy, which borders out into the politics of other countries like Syria, Iraq and Bahrain.

Now, does it matter today whether there is a caliph or an imam at the top of the country hierarchy, as a both secular and spiritual leader? The last real imam disappeared in the $900^{\text {th }}$ century and he will of course never come back. No one can overcome death. The last caliph left for Switzerland on a one way ticket in 1924. These titles, caliph or imam, are not usable in the 21 rst century, as also Moslem countries have to employ a secular structure of power, with the standard institutions of trias politica. Even the only theocracy in the world, Iran, has a formal secular structure of institutions and offices besides "The Spiritual Leader" and the Ulama.

Since the opposition between caliph and imam is of historical relevance only, the best format for running a Muslim state being the legal-rational authority type, or constitutional rulership, the Sunni-Shia split is a mere theologian one, like the split between various Christian groups or sects. Co-existence on the basis of comprehensive tolerance is clearly possible and would strengthen the Islamic civilisation enormously.

The Sunni-Shia clash is a zero-sum conflict with no predictable outcome. This makes it meaningless, as there could only losers. The simple solution to a zero-sum game is the so-called security strategy: maximise the safe gains, hold down or minimise the possible losses. When a conflict is played out once and the strategies and outcomes are fully known, zero-sum games are easy to solve, in pure or mixed strategy choice. However, when a conflict has no end in sight, what is the solution?

One could divide up a conflict in a series of nodes of single play and search for the so-called sub game perfect $\mathrm{N}$-equilibrium, like in variable sum games. However, if the conflict is on-going without an end in sight, then backwards solution cannot be applied. One must look for the Zermelo point in the series of nodes, i.e. the point in time of play after which the game is strictly determined.

A zero-sum conflict that goes over several nodes of play is the chess game. The Zermelo point occurs when the outcome is unavoidable, given correct play. Either white is bound to win and black bound to lose or a draw is inevitable. The most interesting thing about the move by move development of the game is the occurrence of the decisive move, from the outcome is determined. 
In military battles, the Zermelo point is often a fundamental blunder or a genial choice of strategy. Examples: Napoleon's invasion by his grand armé, the Wehrmacht (Ostheer) defeat at Stalingrad, the victory at ALESIA by J. Ceasar, etc.

The conflict between Sunnis and Shias has no Zermelo point. The outcome has no victor or loser, but only human misery. It can go on for one hundred more years, but with no decisive outcome except human suffering. Why cannot Islam accept such a minimum of tolerance that Sunnis and Shias can live side by side, with their separate shrines?

\section{9. "Martyr" Is Based Only on Myth}

When it comes to look at the future of the new jihadism, what is most important is to understand what drives this spreading scourge in the Muslim civilisation. There is no hope of accommodation, as organised terrorism cannot survive side by side with a legal-rational regime.

One maw draw upon two models of terrorism, one micro based and another macro oriented. The micro model attempts to capture the individual motivation of the single jihadists. To engage in jihad activities involving killing fellow Muslims, it must hold that

(1) $\mathrm{Bi}>\mathrm{Ci}$, for individual $\mathrm{i}$

This may be true in the short run when an operation is successful, but unlikely true in the long run, as jihadists have high death rates. Sometimes Salafist terrorists fight each other.

The opportunity costs of being a jihadist can only increase of time, as the values of a normal life is forsaken. Looting is an aspect of terrorist activities, especially in areas where the availability of employment opportunities is almost non-existent. When terrorist can draw upon drug trading, human trafficking and slave trade, the above motivation equation certainly holds. Salafist terrorism is covertly supported by a few Muslim countries, as long as the activities of the jihadists take place abroad.

When jihadism fails, meaning that $\mathrm{Ci}>\mathrm{Bi}$, then the philosophy of martyrdom is invoked. The idea of becoming a martyr though participation in some form of a holy war belongs to these notions like paradise, hell, eternal life, sainthood, etc that may be understood intellectually but do not designate anything in particular in reality. Martyrdom is an illusion, for which it is not worth to die, because after death there is nothing.

Jihadist fighting may be accompanied by huge sacrifices in deaths and casualties in order to evict an intruder, protect the sacred lands of Islam against foreigners or defy an oppressor, to the benefits of the Islamic community as a whole.

Jihadism has expanded a lot since the Second Iraq war, from Afghanistan and Pakistan to Saharan Africa. There is even a self-proclaimed over an Islamic state in Syria-Iraq. Jihadism can only be contained by counter-measures according to the second model of terrorism, modelling the diffusion process:

(2) $d T / d t=f(P)$, terrorist acts depend upon number of perpetrators $P$ :

(3) $-\mathrm{dP} / \mathrm{dt}=\mathrm{f}(\mathrm{dR} / \mathrm{dt})$, the number of perpetrators depend negatively upon the number of restrainers $\mathrm{R}$ increasing over time;

The restrainers could be the national army or an international force like France today in Mali. Restraining jihadist terrorism has proven extremely difficult in weak states. In stable or authoritarian states, jihadism is almost non-existent due to effective but violent suppression like in Algeria, Egypt and the Arab peninsula.

What could be a better place to look for an answer than the Holy Book or the Book of God, viz The Koran. It states a few rules that are pertinent to the question:

1) No Muslim may kill another Muslim;

2) Muslims who are right guided will enter Paradise on judgement day;

3) Muslim who turn infidels will suffer the same fate as all infidels, namely to burn in Hell;

4) Muslims who have been misguided can repent their sins and perhaps receive God's mercy;

5) A right guided Muslim accepts fully the consequences of the five duties.

One finds several places in the Koran where these principles are expressed. How they are to be interpreted depends upon who is to be considered a Muslim, what it entails to be seen as an infidel and what a rightly guided behaviour stands in details.

Islam harbour diversity of opinions in relation to the coherence among the 5 rules above, resulting in major 
schisms and the formation of several sects. Thus, the Sunnis divide themselves in four schools of jurisprudence as well as in modernists and Salafists, after Ibn Taymiyyah (dead 1328). The Shias constitute a most diverse lot, from Iranian and Iraqi fundamentalists with their own school of jurisprudence to modernists in e.g. Turkey, Syria and India. In addition, there is the group of Sufis among the Sunnis.

Now, in relation to the crucial question above, one must ask whether the Sunni-Shia civil war or the jihadists attacks on Muslims can be motivated by these 5 rules of Islam? Salafists claim that Shiism is a blasphemy, because it violates ONENESS (tawdid), regarding Ali and his descending family as somehow a saint besides Allah. Jihadists under the influence of MB sharpen this rejection of Shiism as magic, but jihadism also looks upon moderate Sunnis and Shias as targets of political violence, aimed at islamisation.

The expansion of the concept of infidel to cover not only adherents of other religions but also Muslims with a different faith than Salafism was re-innovated in the $20^{\text {th }}$ century by Mawdudi, Qutb and Faraj - the ideological fathers of Islamisation and Salafist terrorism.

When a Moslem country adheres to the Islamic interpretation of these ideologues of MB, then peace and political stability is not feasible. They stand for an Islam that is as uncompromising with modernity and reason as Khomeiny's Iran. In Islam today, the French saying holds: Les extremes se touchent. And they extended to the scope jihad fighting to include all kinds of infidels, Moslem or others, with deadly repercussions. Jihad as the hidden duty (Faraj) is allowed against anybody who opposes the islamisation of society (Maududi) or the state (Qutb). The political philosophy of Salafist fundamentalism is not derived from The Koran, but constitutes a $20^{\text {th }}$ century dismal innovation in general Islamic philosophy.

In traditional Islamic philosophy with its great representatives during the medieval ages, the focus is upon the relationship between religious faith and reasonable belief. It covers a large range of issues about the origins of universe and life and the nature of human volition and destiny. Political Islam is a recent ideology with no basis in The Koran, emerging in the $20^{\text {th }}$ century out of India (the Deobandi school), Pakistan and Egypt.

One is amazed to read about the number of Muslims volunteering to fight for the ISIS, as it offers a road map to death and humiliation. Young people may be attracted by the conception of a "martyr", but it is all make belief. When people die, they do not exist anymore, neither as spirits waiting for the resurrection nor as travellers to some "Paradise" in the Cosmos.

\section{Constitutional Law, Sharia and Roman Law}

In presentations of the main features if Islamic Law, it is never underlined sufficiently that Sharia is basically private law. Islamic Law developed outside of Western law - Roman Law and Common Law - as the tool for Islamic jurisprudence (figh) to create a minimum of order in the Muslim Empire, growing rapidly after the death of the Prophet, both westward and eastward.

The new societies adhering to Islamic faith needed a fundamental set of rules for the behaviour of the Umma, i.e. the private life of the faithful concerning family, marriage, daily activities, business and commerce. Sharia Law provided this institutionalisation with its four schools of jurisprudence. None of them considered public or constitutional law at any length. It was simply assumed that the caliph or the imam would be a man rightly guided. When the Arab heritage was mixed with other non-Muslim traditions, the assumption remained that the khan, sultan or king (emir) would be right guided. Like Roman Law, Sharia Law spells out the implications of various forms of private contracts, which had to respected ultimately due to divine sanction (Hägerström, 1953).

One may draw a parallel to Roman Law, which was also basically about private law, including criminal law. Corpus Juris Civilis did not regulate public power, which rested in the hands of an Emperor, who made law through "constitutions", meaning commands. The concept of constitutional law as restrictions upon the state emerged in the $16^{\text {th }}$ century in Calvinist Europe. Several Muslim countries imported foreign constitutional law in the $19^{\text {th }}$ and $20^{\text {th }}$ centuries, but public law in Moslem countries never succeeded to establish political order, i.e. rule of law.

Rule of law captures perceptions of the extent to which agents have confidence in and abide by the rules of society, and in particular the quality of contract enforcement, property rights, the police, and the courts, as well as the likelihood of crime and violence." (http://info.worldbank.org/governance/wgi/pdf/rl.pdf)

When public law started to develop, covering both constitutional law and administrative law, it targeted much what is now called rule of law or the Rechtsstaat (Reiss, 1991). It did not call for democracy or the universal franchise, because its goal was law and order under the legal framework. The rule-of- law regime offers constraints upon political power, whether be it the power of political leaders or that of bureaucrats. 
It counteracts a number of vices that political power often succumbs to, including:
(a) Arbitrariness;
(b) Corruption and embezzlement;
(c) Nationalisation of property;
(d) False accusations and unreasonable search and seizure;
(e) Detention without accusation;
(f) Politicised court rulings.

Thus, a country which that honours rule of law upholds rules that restrain politicians and bureaucrats in an effort to promote the outcomes (a) - (f) that, which would be beneficial for both economic life and political liberty.

Where the rules of rule of law are observed, one would not always find democracy. In general it holds that democracy implies rule of law, but the opposite may not hold. Thus, the rule of law set of rules anticipated the democratic regime from a historical perspective, in both the UK and in Continental Europe (Lane 2011). And on the contemporary scene, one finds countries with considerable amount of rule of law, although they do not practise competitive democracy with free and fair elections that may be contested by any political party whatsoever. One may map the spread of rule of law by employing the WB set of indicators on Muslim countries (Diagram 2).

Diagram 2. Rule of law in Muslim countries

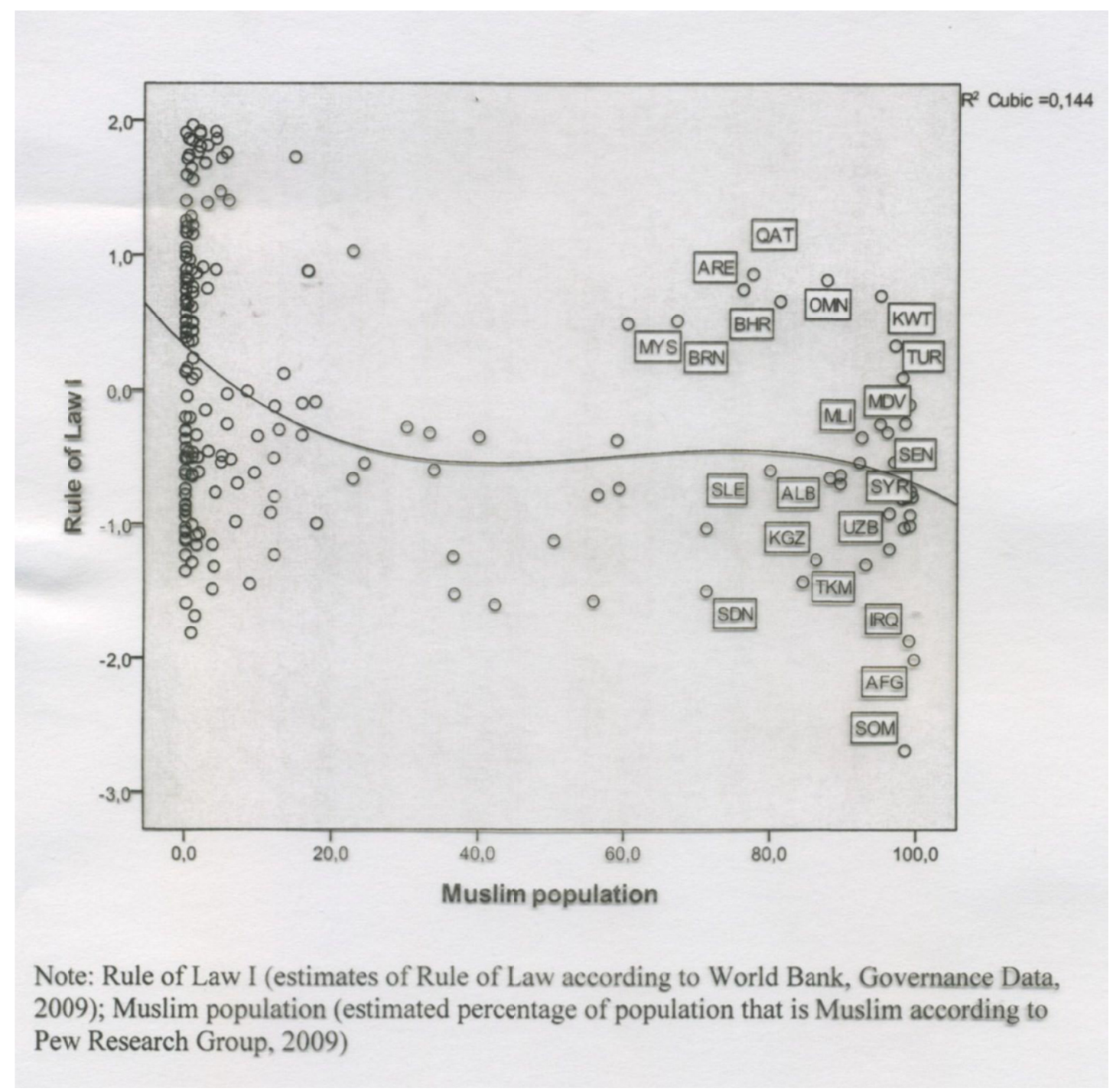


A political regime that runs according to rule of law would satisfy a few conditions that constrain the exercise of political power. Rule of law entails that power is be exercised according to the following precepts concerning due legal process and judicial accountability:

1) Legality (nullum crimen sine lege);

2) Constitutionality (lex superior);

3) Rights and duties: negative human rights (habeas corpus);

4) Judicial independence: complaint, appeal, compensation.

The theory of good governance is based upon the hypothesis that a government adhering to these precepts will be more successful in enhancing socio-economic development than a government that fails to respect these principles. Thus, economic activity will be stimulated by legal predictability, the protection of property, and the autonomy of judges when testing cases for assumed violations of legality or constitutionality (Cooter \& Ulien, 2011).

To Sum Up: The Muslim governments ought to work together with the civil society in their countries to improve the consistently ratings in Diagram 2 above. The increase in Rule of Law scores would mean more to the Muslim population and other groups in these societies than the introduction of democracy, which so far has led to anarchy in several countries. Whether a democratic regime is really feasible in a Muslim country is still a completely open question. Political stability, law and order and rule law is another matter. It already exists to some degree in the kingdoms, which - hopefully - could develop into constitutional monarchies. Without political stability, there will be no end to the sufferings of people in the Islamic civilisation. Rule of law is a MUST!

Life in constitutional monarchies may be supportable, if and only if there is political stability and rule of law. It seems that many of the Muslim republics have fallen into Hobbesian anarchy in their vain search for the democratic regime. The worst are the warring rebels who under the label "jihad" pursue systematic LOOTING. ISIS is the scourge of mankind - but they are merely just looters.

\section{Conclusion}

The amount of political violence has reached a level and intensity in the Muslim civilisation that hurts ordinary people in a manner that has no similarity what so ever in other global civilisations. It gives rise to the question about the religious cleavages in Islam and their implications for political violence and state stability.

It seems as if the Muslim civilisation may implode from inside, leaving numerous countries in civil war, anarchy, anomie, rebellion, attacks against innocents, women and children, looting by rebel groups and destruction of valuable material assets. Three responses have been suggested to the Muslim civilisation decline:

1) Jahiliyyah: the concept for "ignorance of divine guidance" or "the state of ignorance of the guidance from God" or "Days of Ignorance. It would spell the demise of the Muslim civilisation and the end to all the hope among Moslems for a better life in human dignity.

2) Western modernisation: democracy (Held, 1995). It has been tried in several Muslim countries, but only Tunisia seems to be successful. When coupled with the main religious cleavages in may even augment political violence and be cul de sac. Jihadism introduces a so-called war of attrition into country, a most lethal phenomenon that involves fighting over a long time period until one party is exhausted.

3) Institutionalisation of legal-rational authority with government found upon rule of law.

The growing chaos in the Muslim civilisation can only be counteracted by the third alternative above, namely institutionalisation, viz the introduction and enforcement of rule of law. It is more important than promoting the democratic regime in the Islamic world, which only seems to result in new authoritarian regimes or even worse anarchy and rebel chaos.

The institutional deficit in Muslim countries goes back to the so-called Golden Age, as neither the Prophet nor the jurisprudence created anything like constitutionalism. Islamic law deals with private law matters, theft, property, inheritance, marriage, religious matters like the wagf, etc. The worldly matters are left to chance with the restriction that the caliph, sultan, emir, king etc, must never be an infidel.

Modern constitutions were basically imported from the West during the $19^{\text {th }}$ and 20 centuries. But they most often were replaced by naked power or authoritarian constitutional documents. Even more important is the Islamic law lacks the fundamental notions of individual rights under the rule of law framework that became such a vital part of both English law (Common Law) and French-German-Swiss Law (Civil Law). 
Under a feasible rule of law regime with the recognition of The Koran, there is no need for so incredibly much political violence in the Muslim civilisation, leaving Muslims and other groups with peace, the hope of prosperity and religious co-existence of Sunnis, Shias and Salafists.

When the other civilisations in the world power ahead towards higher levels of well-being, parts of the Islamic civilisation destroys for itself, failing to protect the life and assets of its Islamic believers. The French would say: Ca sert a Quoi? Or The Romans would ask: Cui bono?

\section{References}

Adamson, P., \& Taylor, R. C. (Eds.). (2004). The Cambridge Companion to Arabic Philosophy. Cambridge: Cambridge University Press. http://dx.doi.org/10.1017/CCOL0521817439

Adib-Moghaddam, A. (2014). A Critical Introduction to Khomeini. Cambridge: Cambridge University Press.

Ahktar, S. (2007). The Quran and the Secular Mind: A Philosophy of Islam. London: Routledge.

Al-Tamany, S. M. S. (2014). Averroes, Kant and the Origins of the Enlightenment: Reason and Revelation in Arab Thought. London: I.B. Tauris.

Averroes. (n. d.). The Decisive Discours. Retrieved from

http://people.uvawise.edu/philosophy/phil205/Averroes.html

Calvert, J. (2010). Sayyid Qutb and the Origins of Radical Islamism. New York: Columbia University Press.

Cooter, R. D., \& Ulen, T. (2011). Law and Economics. New York: Pearson.

Easton, D. (1965). A Systems Analysis of Political Life. New York: Wiley.

Ellis, M., Emon, A. M., \& Glahm, B. (Eds.). (2010). Islamic Law and International Human Rights Law. Oxford: Oxford University Press.

Fakhry, M. (2004). A History of Islamic Philosophy. New York: Columbia University Press.

Hägerström, A. (1953). Inquiries into the Nature of Morals and Law. Stockholm: Almqvist \& Wicksell.

Hallaq. (2010). An Introduction to Islamic Law. Cambridge: Cambridge University Press.

Held, D. (1995). Democracy and the Global Order: From the Modern State to Cosmopolitan Governance. Stanford: Stanford U.P.

Hobbes, T. (1982). Leviathan. London: Pemguin.

Jackson, R. (2010). Mawlana Mawdudi and Political Islam: Authority and the Islamic state. London: Routledge.

Kamali, M. H. (2008). Shari'ah Law: An Introduction. Oneworld Publications.

Kaufmann, D., Kraay, A., \& Mastruzzi, M. (2010). The Worldwide Governance Indicators: Methodlogy and analytical issues. World Bank Policy Working paper No 5430. http://papers.ssrn.com/sol3/papers.cfm?abstract_id=1682130

Klabbers, J., Peters, A., \& Ulfstein, G. (2011). The Constitutionalization of International Law. Oxford: Oxford U.P.

Krisch, N. (2011). Beyond Constitutionalism: The Pluralist Structure of Postnational Law.

Lane, J.-E. (2011). Constitutions and Political Theory. Manchester: Manchester U.P.

Leaman, O. (2009). Islamic Philosophy: An Introduction. Cambridge: Polity Press.

Leaman, O. (2009). Islamic Philosophy: An Introduction. Cambridge: Polity Press.

Malthaner, S. (2011). Mobilizing the Faithful: Militant Islamist Groups and Their Constituencies. Chicago: University of Chicago Press.

Nasr, S. H. (2006). Islamic Philosophy from Its Origin to the Present: Philosophy in the Land of Prophecy. New York: State University of New York.

Rapoport, Y., \& Ahmed, S. (Eds.). (2010). Ibn Taymiyya and his Times. Oxford: Oxford University Press.

Reiss, H. S. (1991). Kant's Political Writings. Cambridge: Cambridge U.P.

Roy, O. (2009). The Politics of Chaos in the Middle East. Oxford: Oxford U.P.

Sayed, K. (2009). The Political Thought of Sayyid Qutb: The Theory of Jahiliyyah. London: Routledge.

The Koran. (1995). London: Penguin. 
Winter, T. (Ed.). (2008). The Cambridge Companion to Classical Islamic Theology. Cambridge: Cambridge University Press. http://dx.doi.org/10.1017/CCOL9780521780582

Wohlman, A. (2013). Al-Ghazali, Averroes and the Interpretation of the Qur'an: Common Sense and Philosophy in Islam. London: Routledge.

Wolrd Bank. (2012). Governance Project. Retrieved from http://info.worldbank.org/governance/wgi/

\section{Note}

Note 1. Jan-Erik lane is an independent scholar who has been full professor at 3 universities and visiting professor at many more.

\section{Copyrights}

Copyright for this article is retained by the author(s), with first publication rights granted to the journal.

This is an open-access article distributed under the terms and conditions of the Creative Commons Attribution license (http://creativecommons.org/licenses/by/3.0/). 